\title{
Integration Capacity of Russia's Far East in Multipolar World
}

\author{
Mikhail Sorokin ${ }^{1, *}$ and Aleksei Sorokin ${ }^{2}$ \\ ${ }^{1}$ Vladivostok State University of Economics and Service, 41 Gogolya st, Vladivostok, 690014, Russia \\ ${ }^{2}$ Peoples' Friendship University of Russia (RUDN University), 6 Miklukho-Maklaya St, Moscow, \\ 117198, Russia
}

\begin{abstract}
The article offers to discuss the topical issues of areas and opportunities for development of the Far East of Russia in multipolar world. Today, multipolarity is a characteristic feature of globalization. The author considers the integration with the countries of the Asia-Pacific region as an opportunity to mitigate the negative demographic processes which are manifested in ongoing out-migration. Moreover, the migration outflow is five sixth. The Russian government proclaimed 'a turn to the East" in its foreign policy. The article aims at identifying new, not based on natural resources use, factors of the Far East's integration into the AsiaPacific region. The study shows that a relatively small population, poor transport infrastructure and lack of requirements made by a large part of population for the quality of goods and services, as well as the devaluation of the national currency, would not be the factors contributing to a great demand for the goods from the Asia-Pacific countries. It is therefore necessary to search for the integration capacity of the Russian Far East elsewhere. By summarizing scientific evidence, the author highlights that they could be natural recreational resources and participation in resolving global, including environmental, challenges.
\end{abstract}

\section{Introduction}

The Far East region is indeed a unique region. The significant reserves of mineral resources are concentrated here. The region currently produces $98 \%$ of diamonds, $80 \%$ of tin, $90 \%$ of borates, $60 \%$ of fish and seafood, $50 \%$ of gold, $15 \%$ of wolfram and $13 \%$ of wood. On the other hand, a proximity to growing markets of the Asia-Pacific region, covering $40 \%$ of the world population, shaped a comparatively narrow commoditydependant segment of Russia's participation in the system of economic ties of the AsiaPacific region. This aspect gives rise to the scientific search and justification of other, not based on resources use, Russia's integration directions in the Asia-Pacific region.

There is quite a lot of scientific works focused on the ways of integration of states into the system of world economic relations, among which we mention the "Trade policy and the importance of accession to WTO for the development of Russia and CIS countries: a guidebook" by David G. Tarr [1], a report of the Center for External Economic Studies of

\footnotetext{
*Corresponding author: sma-vlv@yandex.ru
} 
the Institute of International Economic and Political Studies, a monograph "Russia in a Globalizing World" edited by academician D.S. Lvov, and G.B. Kleiner, Corresponding Member of the Russian Academy of Sciences, and others. There are research works by P.Ya. Baklanov [2, 3], M.T. Romanov [3, 4], I.I. Melamed, A. A Diagilev, M.A Avdeev [5], A.A. Miroedov and I.I. Saveliev [6], I.M. Zaychenko and O.V. Kalinin, and Gutman [7], and others $[8,9]$.

For our study we apply general theoretical methods such as analysis, synthesis, and opposition.

\section{Experimental section}

The information data were obtained from official websites of the EconomyNews and TrandEconomy, L.L. Rybakovsky's website and business circles of the Far East. Methods of analysis, synthesis, opposition and comparison were used.

\section{Results and discussion section}

A few years ago, the world community entered a new phase of globalization. Despite the globalization as a process of strengthening ties of different trajectories (especially economic ones) is characterized by sustainable dynamism, however, we can safely conclude that there are new factors having an impact on global processes. First of all, we note a shift from chaos to governance of these processes.

The dichotomy of the world economy "globalization - regionalization", in our view, is shifting to regionalization but, as the history illustrates, it is a commuting process.

The bipolar system of the world economy, which was formed after the Second World War and based primarily on ideological imperatives, lasted for several decades. Obviously, the confrontation between the two systems (socialist and capitalist) has largely determined the future development of humanity. Although from the classical perspective economic competition was for the most part concentrated inside these systems. Free international competition within the Porter's understanding was limited to various political and trade barriers.

With the downfall of the Soviet Union, and then of the socialist camp, the world headed towards a unipolar world. Globalization was given tangible features in the form of an institutional framework. Here, against the background of loss of economic and political might of the USSR, a unipolar world order, subordinated to the interests of the USA and its allies, started shaping. The People's Republic of China was not considered at all as a relevant and / or valuable player on the world economic and, therefore, political arena in the beginning of the fourth quarter of the 20th century. It is enough to turn to M. Porter's fundamental work "International Economics" (1993), which analyzes the economic development of Switzerland, Sweden, Germany, the USA, Japan, Italy, Korea, but not China [10]. During the period of China's gradual emergence on the international arena (as a serious political and economic powerhouse) a characteristic feature of globalization was the creation of supranational structures, either subordinates or working in the interests of a limited number of states with the USA administration [11]. Developed in the 1990s, the Washington Consensus was the basis for the formation of a unipolar model of globalization, with each state having a strictly defined role [12].

The enhancement of political, economic, military positions of China, Russia, India, Brazil and other countries, as well as the development an active phase of regionalization, created an objective basis for multipolarity. It is obvious that neoliberalism as the prevailing scientific trend, which justifies a monopolar development of globalization, is mired in a serious crisis. On the other hand, the current stage of globalization, which, in our view, 
started in 2014, is characterized not only by the imposition of sanctions on the Russian Federation, but also by leading world states' cessation of implementation of their international obligations. The US actions with respect to the Russian Federation diplomatic property provide a striking example of this. In addition, the US refusal to take part in the Trans-Pacific Partnership, which was established (and almost created) beyond the area of concerns of Russia and China, shows that global interests are now giving way to national ones. And at the last World Economic Forum in Davos (2018), most representatives agreed with the view that protectionism in world trade is gaining momentum [13].

We propose to single out the features of multipolarity, either explicitly or implicitly manifested in the international trade and political relations at the present time.

Firstly, it is a regionalization, characterized by creation of regional trade and economic associations. Free trade zones and customs unions have proved their advantages, providing developing countries with new opportunities for industrial cooperation [14]. For Russia, first towards creating the Customs Union (Russia, Belarus, Kazakhstan) and, then the Eurasian Economic Union, is a major geopolitical accomplishment. Russia has proved to the world community the need and the possibility of creating a union of equal states (albeit not equal in territory, population, GDP, etc.).

Secondly, the US is gradually losing the role of a superpower on the global economic arena. Placing restrictions (import customs duties) on a group of consumer goods from China (about $10 \%$ of Chinese exports to the USA) indicates not so much care of the White House authorities about national producers, but rather about the growing power of China's economy. In addition, a recent increase in the rates of export customs duties (against the background of China's renounce their application) on rare earth metals with impunity are relevant here.

Thirdly, emerging trade and political blocs in the Asia-Pacific region are increasingly oriented towards local, internal rather than global markets. Here, a significant increase in population's standard of living, a diversification of industrial production with a focus on consumer products and services, as well as building a mainstream culture of consumer individualism (mainly by means of the mass media) are the key factors. For example, over the past 10 years, a demand for medical services on changing identity, increase in life expectancy, etc. has grown considerably in the Republic of Korea.

Fourthly, the sanctions policy of developed countries in respect of Russia is increasingly seen as a pretext for 'supranational' restriction of competition in world markets, primarily financial and energy ones. It is obvious that the mechanisms of sanctions and anti-sanctions are not still working for stated objectives. Our country had certainly to respond to many partners' unfriendly actions, primarily by conducting a devaluation of the national currency in the fall of 2014.

Under the circumstances, the processes of building the multipolar shape are focused in the perspective of expanding integration at the regional level.

In scientific publications of recent years there is no general consensus on the relationship between regionalization, integration and globalization. Some scientists believe first come integration processes, then they transform into somewhat different quality - globalization [15]. Others assume that integration is an essential attribute and precondition of globalization. We share G. Kolodko's point of view, the Polish scholar, which singles out liberalization, integration and interdependence as globalization attributes [16].

The Russian Federation as a developing country actively supports both globalization and regionalization processes, striving for being a full partner in the global economy [17]. In the Asia-Pacific region, Russia is a member of the largest trade and political organization - the Asia-Pacific Economic Cooperation Forum (APEC). Today, APEC is the largest regional association, including 21 economies. By emphasizing the economic nature of the association, APEC members tacitly call themselves not states, but economies. The APEC 
principles include cooperation only in economic sphere, absence of a special administration, voluntary and non-binding consensus-based decisions, open exchange of information, abandonment of tight planning prospects for the development of Forum. The APEC objectives comprise trade and investment liberalization, trade facilitation, economic and technical cooperation [8].

Despite Russia is an APEC member since 1997, the 'turn to the East in Russia's foreign policy has occurred more recently. In our opinion, this is due not so much to the weakening of trade and economic ties with the European Union countries that have been our the largest trading partners for many years, but rather to almost catastrophic demographic processes and trends in the Russian Far East.

The population of the Far Eastern Federal District was 6.182 million people (less than 5\% of the country's population) as of 01 January, 2017. It is the most sparsely populated region of the country. If for the period of 1970-1990 the population had increased by 2.225 million people (from 5.870 million to 8.060 million), then over the next 27 years it had decreased by 1.872 million people (Figure 1 ).

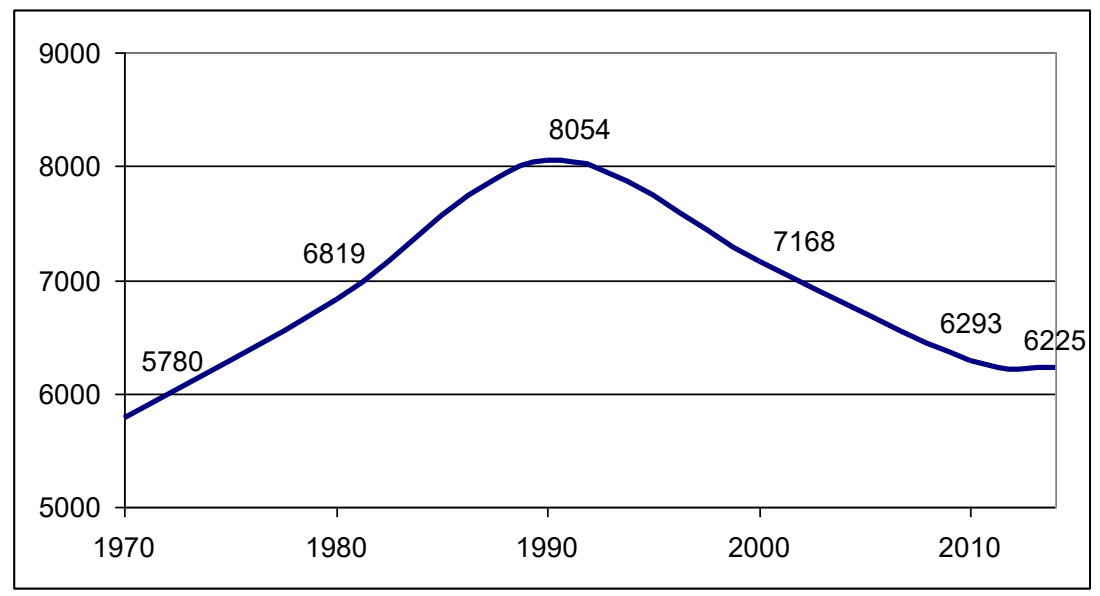

Fig. 1. Population Dynamics of the Far East of Russia (1970-2014, thous. people).

That is, for more than 25 years of market reforms the population of Russia's Far East had declined by almost a quarter, while in the same period the population of Russia had decreased by $3.7 \%$ [18]. Moreover, according to the principal researcher of the Institute of Social and Political Studies, Doctor of Economic Sciences, Professor L.L. Rybakovsky, in population decline there is one sixth of natural population decline (excess of death rates over births) and five sixth of migration loss [19]. Here, we note that official statistics document and record only cases of change of residence, while thousands of young people leave the Far East without losing (for many reasons) registration at their place of residence.

Thus, the problem of consolidating people in the Far East under the present day circumstances is being transformed into the problem of retaining the Far East itself. Indeed, this is a huge challenge, not a task, after all, the task, as a rule, has a solution. The Russian government found an integrated approach to tackling this challenge. The State program for social and economic development of the Far East and the Baikal region was approved until 2025. It consists of 12 subprograms with federal budget funding of 3.8 trillion rubles. The major projects with direct State participation such as the development of Vladivostok as a center for international cooperation in the Asia-Pacific region, the construction of the Vostochnii Space Launch Center, the development of the Far Eastern Federal University and others are being implemented. There is a legal framework adopted for territories with special economic regimes (the Federal Law dated 29 December, 2014 No. 473-FZ "On the 
Territories of Advanced Social and Economic Development in the Russian Federation" ; the Federal Law dated 13 July, 2015 No. 212-FZ “On the Free Port of Vladivostok ". There has been launched the revival of the Arctic Northern Sea Route, the construction of the "Siberia Power" gas pipeline and the "Eastern Siberia - Pacific Ocean" oil pipeline, "A Hectare in the Far East" project.

There is no doubt that many of these activities are focused on intensifying integration of Russia and of the Far East, in particular, into the system of world economic relationships of the Asia-Pacific region. Nevertheless, such a pursuit must be mutual. Regions, states and economies are integrated, but people, their interests, traditions, mentality, background and others still remain the elementary cell of the process. S. Kim, the head of the export department of the Asia-Pacific Trade Company, made it clear about the peculiarities of business in China: "The Chinese are the best sellers in the world and the worst buyers" [20].

Let us look at the assessment of areas for incorporation of the Russian Far East in detail.

Firstly, the integration of the Far East into the system of economic relations of the AsiaPacific region, in our view, should not be based only and exclusively on processing natural resources of Russia and other foreign countries. Moreover, possessing a significant amount of natural resources is not often a factor of integration. Here, it is necessary to separate integration and international trade in mobile factors of production [21].

Secondly, from the perspective of market demand, the population of the Russian Far East for the APR countries is not of high interest. There is a relatively low population density, huge distances and poor transport infrastructure, which is mainly designed to main an average quality of life of the most part of population. Even taking into account a high competition on the commodity markets in the Asia-Pacific region, the factors mentioned above, coupled with the prospects for further devaluation of ruble, make the Far East market unattractive.

Thirdly, the integration capacity of the Russian Far East in the 21st century, in our opinion, will be determined by two elements: the natural and recreational opportunities of the territory and the active involvement of our country in global projects in the interests of all countries of the macro region.

Natural and recreational opportunities (despite the relatively severe climate of the Far East) can be in demand in agricultural production (grain, vegetables) and livestock. Large companies of China, Japan, the Republic of Korea show a serious interest in agricultural segment with the condition of export of products. First and foremost, they are attracted to the considerable area of arable lands (Figure 2) [22, 23], as well as to the possibility of obtaining environmentally friendly products and biofuel.

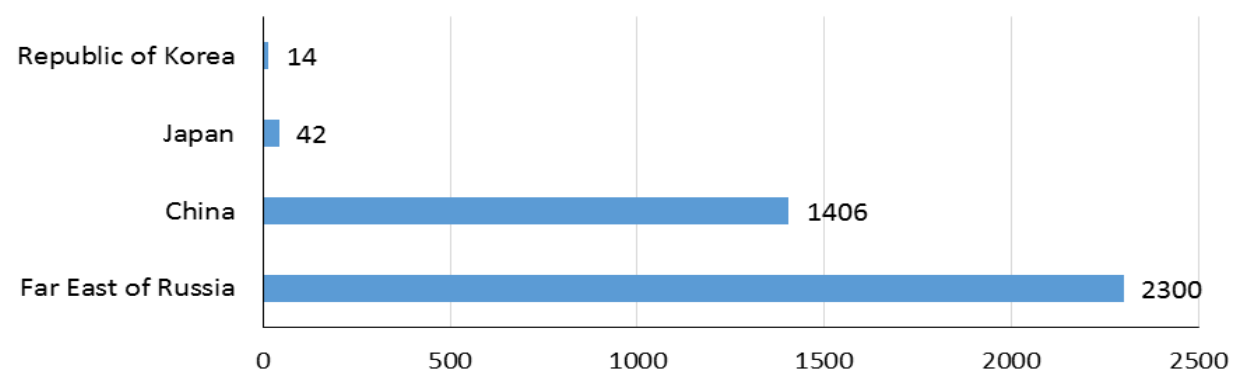

Fig. 2. Arable land of the Far East of Russia, China, Japan and the Republic of Korea, thous. sq. km.

The ecological vector of international cooperation can be based on joint use of scientific and technical capacity in the interests for the benefit of all countries of the region. As the accident at the nuclear power plant in Fukushima (Japan) showed, the countries of the 
region consider the environmental security a global problem, and its solution is a condition for sustainable development. Russia here can offer not only advanced technologies, but also become a part of a macro-regional ecosystem. Moreover, many environmental projects are possible to implement on land, in the sea and atmosphere.

\section{Conclusions}

The article highlights a new phase of globalization, characterized by increasing protectionism, which mainly manifests in non-economic management of international world. It is shown, that the regionalization is a condition for building multipolarity. The study offers an idea on the necessity and possibility of mitigating negative demographic trends in the Russian Far East by integrating the Russian Far East into the system of the economic relations of the Asia-Pacific region, which is not based on trade of natural resources.

Subsequent studies will be aimed at identifying and justifying the administrative and economic mechanisms for such integration.

\section{References}

1. G. David, Trade policy and significance of WTO accession for Russia and CIS countries. Guidebook (Ves' mir Publ., Moscow, 2006)

2. P.Ya. Baklanov, P.A. Minakir, Territorial structures of the economy in regional management (the Pacific Geographical Institute FEB RAS, Moscow Nauka Publ., 2007)

3. P.Ya. Baklanov, The economic and geographical and geopolitical position of Pacific Russia (Dal'nauka Publ., Vladivostok, 2009)

4. M.T. Romanov, Territorial organization of economy of undeveloped regions of Russia (Dal'nauka Publ., Vladivostok, 2009)

5. I.I. Melamed, A.A. Dyagilev, M.A. Avdeev, The main approaches to the development of the Far East and Bailkal region (Sovremennaya ekonomika i pravo Publ., Moscow, 2010)

6. A.A. Miroyedov, I.I. Savel'ev Control of export potential of the region (Inf. Isl. Tsentr Statistika Rosii Publ., Moscow, 2012)

7. I.M. Zaychenko, O.V. Kalinina, S.S. Gutman, Labor resources of the Far North territories: Problems and prospect, «Proceedings of 28-th International Business Information Management Association Conference» (Seville, 2016)

8. S.A. Sitaryan, Strategic guidelines for Russia's foreign economic relations in the context of globalization: the scenario until 2025 (Nauka Publ., Moscow, 2005)

9. D.S. L'vova, Russia in globalizing world: modernization of the Russian economy (Nauka Publ., Moscow, 2007)

10. M. Porter, International competition (Mezhdunarodnii otnoshenia Publ., Moscow, 1993)

11. A.K. Subbotin, Hypercompetition and Management Effectiveness: Analysis of the Economy of the Leading Countries of the World: A View from Russia (Knizhnyy dom LIBERKOM, Moscow, 2012)

12. V.V Perskaya, M.A Eskindarov, Competitiveness of the national economy in the conditions of multipolarity: Russia, India, China (Ekonomika Publ., Moscow, 2015) 
13. Official website of EconomyNews, http://www.econominews.ru/mirovajajekonomika/535-vsemirnyjj-jekonomicheskijj-forum-v-davose-2018.html

14. V.G. Sherov-Ignat'yev, Customs Unions in globalizing world (SPbGU Izdatelskii dom Publ., Saint-Petersburg, 2012)

15. L.N. Garusova, Regional aspects of modern international relations: the Asia-Pacific region (VGUES Publ., Vladivostok, 2012)

16. G.V. Kolodko, The world in motion (Magistr Publ., Moscow, 2009)

17. V.I. Kurilov, I.I. Melamed, E.A. Terent'yeva, A.L. Abramov and A.L. Lukin, AsiaPacific Economic Cooperation: yesterday, today, tomorrow (Dal'nevostochnyy federal'nyy universitet Publ., Vladivostok, 2010)

18. E.L. Motrich, Bulletin FEB RAS 1, 29-36 (2013)

19. Demographic potential of the Far East, its dynamics and quality, http://rybakovsky.ru/naseleniereg1.html

20. Way to China, http://www.konkurent.ru/article/17032

21. B.B. Loginov, A.O. Rudneva, International factors of production in national economies (INFRA-M Publ., Moscow, 2012)

22. URL : http://data.trendeconomy.ru/dataviewer/wb/wbd/wdi?ref_area $=J P N \&$ series $=A G$ _LND_ARBL_HA

23. URL: http://dvkapital.ru/specialfeatures/dfo_18.04.2014_6126_ 